\title{
The Analysis on New China's Diplomatic \\ Standpoint of the Basic Practical Principles
}

\author{
Hongxia Liu \\ College of Humanities, Zhongnan University of Economics and Law, Wuhan 430079, China \\ Tel: 86-27-631-32921Ｅ-mail: hongxialiu866@yahoo.com.cn
}

\begin{abstract}
New China's diplomatic basic standpoint, namely, the new Chinese diplomacy has always been based on the Third World, this paper has analyzed the theoretical policy-basis why new China's diplomacy based on the Third World and the basic principles that should be adhered to in diplomatic practice, and regarded that the new China's diplomacy can be established in the Third World better, new China's diplomacy will have more achievements in the Third World.

Keywords: New China's diplomacy, Diplomatic standpoint, The third world

Throughout more than 50 years, with an overview on the development and evolvement of the basic standpoint thinking of New China's diplomacy, the diplomacy practice and achievements under its guidance, we can easily find out the basic idea that three generations of leaders on this strategic issue comes down in one continuous line. New China's diplomatic basic standpoint has a unique development and evolvement track and has its own theoretical policy basis and practice principles.
\end{abstract}

\section{The Principles of Diplomatic Standpoint}

In the diplomatic practice of more than 50 years since the establishment of New China, maintaining and strengthening the unity and cooperation with the Third World has always been the basic standpoint of China's diplomacy. The author believes that adhering and developing the basic diplomatic standpoint ideological have the following main policy and theoretical basis.

\subsection{Foreign policy has provided the basis for the basic standpoint of new China's diplomacy}

China unswervingly pursues an independent and peaceful diplomatic policy, the basic objective of this policy is to safeguard the China's independence, sovereignty and territorial integrity, and create a favorable international environment for China's reformation and opening up and modernization construction as well as safeguard world peace and promote common development, and these include:

1) China opposes hegemonism and safeguards world peace. China believes that countries, big or small, strong or weak, rich or poor, are equal in the world community. Disputes and conflicts of different countries should be resolved through peaceful consultations, should not resort to sword or the threat of sword and not use any pretext to interfere internal affairs of other countries.

2) China has been actively promoting the establishment of a fair and rational international political and economic new order. China believes that the new order should reflect the request of historical development, advance of times, the common aspiration and common interests of the world people. Five Principles of Peaceful Coexistence and other universally recognized norms governing international relations should be the basis of the establishment of new international political and economic order.

3) China is willing to establish and develop friend and cooperative relations with all countries on the basis of the Five Principles of respecting each other's sovereignty and territorial integrity, mutual nonaggression, noninterference in each other's internal affairs, equality and mutual benefit and Peaceful Coexistence. The basic standpoint of China's diplomatic policy is to strengthen the solidarity and cooperation with the broad developing countries. Opposing hegemonism and establishing a new international order is the common aspiration of the broad masses of the third world countries and people, this meets the essential interests of the world people's, including the Third World. As a result, to achieve these goals, China' diplomacy must depend on the Third World fundamentally. In other words, China's essential diplomacy standpoint should be based on the Third World.

1.2 The national interests decide China's basic diplomacy standpoint established on the Third World (the developing countries) 
For the relationship between the national interests and diplomacy, the expression of British knight, Palmerston, is rather profound and clear, "We have no permanent friends, and we have no permanent enemies. Only our interests are immutable, what we should follow and pursue is just these interests." Therefore, no permanent friends, only permanent interests, this word has become the golden rule of the country's diplomacy. This" interest ", referring to the national interests, it is the fundamental starting point and ultimate destination of diplomacy. National interests are a historical category, just the entity of stability and dynamic. The so-called Stability refers to that nation's core interests in a certain period are to be fixed. Although diplomacy history of 59 years forms all the diplomacy history of new China, but for the history of China, it is just a little spoondrift in the long river of history. Thus in this period, even though there are ever-expanding dynamic side of China's national interests, but overall the core interests does not change, the changeless core interests decide the diplomatic strategy will not change. Here, the core interest is security interests and economic interests (security interests and economic interests are the fundamental guarantees for the survival of a sovereign country), the diplomatic strategy include the strategy of standpoint. Therefore, the core national interests decide the diplomatic strategy, and then the relative stability of the core national interests decides the stability of the basic diplomacy standpoint. Therefore, the essential theory that considers the national interests as the deciding factor of diplomacy provides strong theoretical support for new China's basic diplomacy standpoint basing on the Third World all the time.

\subsection{The common historical experiences and the same identity destine the China's diplomacy must be based on the Third World}

Like other Third World countries, China also is the enslaving, oppressing and exploiting objects of imperialism and colonialism, just like other Third World people, Chinese people also fight for national liberation, national independence and safeguarding the country's sovereignty against the imperialism, colonialism and hegemonism, it is precisely because of these common historical experiences, and China was deeply branded with the Third World mark. As early as in 1955, when participated in the first Asian-African Conference, Zhou Enlai advanced: "since the modern era, the overwhelming majority of Asian and African countries and people have experienced and now is still suffering from the disaster and lifting caused by colonialism...Finding a common basis from wiping off colonial suffering and disaster, we can easily understand and respect mutually and support and sympathize with each other rather than mutual doubt and fear and exclude and oppose mutually." The thought that reckon China and the other Third World countries must depend on, support and development mutually all the time is deep-rooted in China. This in China has never been changed, in spite of the change of leaders or domestic policy changes, or foreign policy adjustments. These natural common grounds existing in China and the other Third World countries is not only the fundamental causes of the new China to support the independence movement in the Third World national liberation movements, but also the action basis of China's fighting against the West for the human rights that wins the support of the broad masses of the Third World countries, and solid foundation of China's further developing friendship and cooperation and coordinating action. Based on this consideration and common identity recognition, China has always stressed that he is a member of the Third World, and adheres to the Third World as the standpoint of China's diplomacy.

1.4 The fundamental attribute of socialism determines that China's basic diplomatic standpoint must be placed on the Third World (the developing countries)

China is a socialist country, China's national interests and the fundamental interests of the world peoples are the same. In socialist China, the diplomatic tenet is to oppose hegemonism, safeguard world peace and promote common development. The tenet requests China to strengthen solidarity and cooperation with the Third World for foreign operations adhere to the "combination of patriotism and internationalism." In the contemporary context of globalization and multi-polarization, the Third World is the important political force to oppose hegemonism and safeguard world peace and the natural allies that China can rely upon to achieve diplomatic tenet. In addition, the number of the Third World countries is $3 / 4$ of the world, and the population $4 / 5$, for what China regards the Third World as the basic diplomatic standpoint accords with China's socialism mission and struggling goal of communism. In order to achieve the highest goal we must adhere to the fundamental guidance of Marxism and combining patriotism and internationalism together. As a result, China has always maintained that "China has the responsibility and obligation to support the oppressed nations and Third World countries' just action to strive for and safeguard national independence and develop the national economy." Just as Mao Zedong in 1959 when he met African friends said: "We can expect, in the future, the anti-imperialist movement of African will develop faster than the past...all peoples, especially the socialist countries, the independent country must help and support you. You need support, we also need your support, and also all social countries need to support each other. Who is going to support us? It's just Asia, Africa and Latin America's national liberation movements...so it is mutual support. Your anti-imperialist movement is our support either. Soviet Union and China do a good job, this is your support. China's "combination of patriotic and internationalist" concretely shows in new China's diplomatic practice, such as Aid North Korea, the Vietnam War against the United States, these actions not only support the independence and liberation of neighbors, but also exclude the threat that imperialist hostile forces exerts on China, so as to maintain China's sovereignty and security interests, that's the vivid 
reflection of combining patriotism and internationalism together.

\section{The First Principle: Handling the Relationship Appropriately with the Third World Countries}

Since October 1949, every leaders of China have attached great importance to the relationship with the broad masses of the Third World, and always consider strengthening the unity and cooperation with the third world countries as a basic standpoint in the foreign policy all the time. Most third world countries support China in a number of important international issues. For example, just because of the strong support of the broad masses of the Third World China resumed legitimate seat in the United Nations in 1971. After the 1989 political turmoil, similarly, the leaders of the Asian-African third world countries visit China firstly against the impact of the West sanctions, and also welcome Chinese leaders' visit with great hospitality. After the Cold War, also with the strong support of the African countries, China foiled 11 times anti-China overtures of Western countries in the conference on human rights, thwarted 13 times Taiwan's "participation and back" to the United Nations proposal, thwarted 9 times Taiwan's "participation" in World Health Organization intentions. Recalling Chinese relationship with the third world countries, there are many successful models, but something worth considering either.

2.1 The Third World is not a monolithic whole, to some extent, is a combination of term and thus China's Third World diplomacy is necessary to emphasize tactics also behave actively

On the one hand, with the common historical experiences of being colonized, exploited and oppressed, the Third World also have ever faced the common task to strive for national independence, safeguarding the country's sovereignty and developing national economy, now still have the desire to develop further economy and society, and build the new international order, which in theory is an abstract entity, so China's diplomacy in theory usually treat the Third World as an independent whole. This strategy not only won for China of that time wide sympathy and support, a good international reputation and diplomatic environment, meanwhile, won tremendous political force for the rising China today and created a new full-scale diplomatic situation. However, on the other hand, the Third World includes more than 160 countries that are different in history, culture and political system and spans across Asia, Africa and Latin America, thus, they are various, but also full of contradictions, differences and conflicts (there are differences between them because of national interests even serious differences. Moreover, in order to battle for spheres, the powerful and hegemonical countries also often provoked many contradictions between them in the Cold War). China's diplomacy in the practice of these colorful personalities, these contradictions, differences and conflicts has realistic achievement. For example, in the face of Western pressure of peaceful evolution, Chinese leaders often stressed, "The world is colorful, the historical stages of every countries, cultural backgrounds, social systems and concepts of values are different, and our way of life are quite different, this diversity of the world is just the source of vitality and innovation. Therefore, respect for and develop the diversity...so that we can conform to the trend of human society development." For the internal contradictions, differences and conflicts of the Third World, Chinese government scrupulously abides by the principles of neutrality and non-interference in internal affairs, the most cases is also quite successful. For example, on the Kashmir dispute between India and Pakistan, the Iran-Iraq war, the Cyprus issue and the Sahara issues and so on, China pursues an impartial and neutral stance, advocating the contradictions and disputes between them should be resolved based on the spirit of mutual understanding and friendly consultations and through peaceful negotiations. Theory and practice are not always consistent, and because of the strategic need, China's diplomacy in theory should continue to treat the Third World as a whole, for practical considerations, for the contradictions, differences and conflicts of the third world countries, the practice of Chinese diplomacy should be active, but at the same time we should avoid directly involve in and cross swords with the other major powers.

\subsection{Properly dealing with the contradictions and differences existing objectively between China and other Third World countries, because all diplomatic actions taking national interests for the highest criteria}

Recalling the history of relations between China and the third world countries, it is easy to find, since China and the broad developing countries have many things in common, China often regards the interests of developing countries and China as the same, moreover, regards China's diplomatic objectives as the third world country's diplomatic objectives. In a certain period of history, the common ground between China and other Third World can unite them and form a powerful political force, but at the same time we should also recognize that many objective differences between the two sides also exist. Firstly, the vast majority of developing countries are nationalistic countries, the guiding ideology is nationalism, and most of its development road is bourgeois parliamentary system. Therefore, in the Cold War period with the ideological confrontation as one major indicator, the differences between the two were particularly obvious. Secondly, the international situation determines a country's diplomatic policy. During the Cold War, the Third World scattered dispersedly, their forces are weak and effect is little, and being in a crevice between two conflicting camps, some of them adhered to the major western powers hostile to China. After the Cold War, the United States has become the world's sole superpower, the majority of Third World countries "West-dumping" trend is serious, and many countries fall to "one-sided". Although third world countries and China have many common interests, but some of these countries still hesitate in many specific issues and bow to Western pressure. For example, for the US-British air strikes 
against Iraq and the US-led NATO bombing of Yugoslavia, in Africa, only South Africa and Egypt publicly denounced NATO's atrocities, most other countries are forced to swallow their rage. These contradictory mind and diplomatic behavior have a clear difference with China. Moreover, China and other third world countries have the same economic structure, similar technological level, the same export products and target group, as a result, there is competition. This is bound to result in contradictions between the two sides in attracting investments, scrambling technological and market. Thus, handling well the differences and contradictions between the two sides will become an important issue of China's diplomacy. From the fundamental starting point of national interests and according to the specific conditions of different countries, China establishes mutual reciprocal, mutual beneficial win-win bilateral relations.

\subsection{Changing the bypast way of free aid and establishing the new aid mechanisms of mutually beneficial and cooperative}

It is not wise to use free aid as a mean of developing relations with other countries, and it's a kind of lopsided relationship between countries based on assisting and being assisted. During the Cold War, China has provide vast numbers free aid for the vast majority of these Third World countries, the vast majority of these are of no conditions attached, China's foreign aid experts also asked to enjoy the same living and wages as the experts of the countries being aided. As a part work of diplomacy, these aids are carried out as the "political task" to some extent, but not consider the economic effect at all. In fact, this assistance does not conducive to the self-reliance development of the being aided, on the contrary, it leads to the dependence psychology of the being aided. After such dependence psychological formed, once their requirements are not meet, it will result in deterioration of relations. For example, Albania and Vietnam, which accepted China's largest aid, is a typical example. Facts show that the relations established on the basis of assistance is not a normal diplomatic relation. Of course, the author does not entirely negate and oppose foreign aid, but the crux of the problem does not lie in whether the assistance should be provided or not, and lie in how assist and whom should be assisted and how many should be assisted and so on. China should inherit the tradition, and at the same time advance with the times, appropriately adjust outdated policies, create new policies and establish new principle and mechanism. With national interest as the criteria basis, China decides its foreign aid policies openly, rationally, transparently.

\subsection{China's great power diplomacy must first strengthen diplomatic foundation}

In the course of construction and development of big-power diplomacy, China should not forget that the diplomacy with the third world countries is the basis of Chinese diplomatic work, the foundation can only be strengthened rather than weakened. China now belongs to the Third World, in a very long period she will still belong to the Third World, even if future development, we must always stand on the side of the broad third world countries. China and the broad third world countries have a profound and historical origins and a wide range of common interests. In sharp and complicated international struggle, the broad third world countries have been China's reliable allies all the time. China gradually joined in the ranks of the major powers today, the third world countries not only remains the political foundation of China's all-round diplomacy, as well as an important sales market for products and supply market of many important raw materials. Followed the building of the big power diplomacy, China should also consolidate and strengthen the diplomatic strategy with the Third World. We should strengthen the political relations with these countries designedly, including high-level exchanges and personnel exchanges, meanwhile, enhance economic and trade relations and give appropriate care in the normal exchanges. So far, China has set up China-Africa and China-Arab Cooperation Forum and established a free trade zone with the ASEAN countries. All these are effective forms to promote multilateral cooperation in the way of bilateral cooperation and it should be gradually deepened based on pragmatic. For Latin American, Caribbean and South Pacific countries, China should also actively explore, paving the way to with economic and trade cooperation, strengthening various areas and forms cooperation, squeezing "Taiwan independence" forces and further expanding China's influence in the world.

\section{The Second Principles: Handling the Relation well with the Western Countries}

Objectively speaking, the strong country is the dominant force in world development, is the founder of the world pattern. The changes of power contrast between strong countries affect the changes of the entire international situation, thereby affect every country's foreign policy adjustments. So the major powers relation should become the focus of every country in the international community normally.

\subsection{Carry out big power diplomacy actively}

For Realism School, the essence of international politics is power politics. Although this view is of great power and hegemony meaning, but it is a true portrayal of the international community. In the international society, the relations among major powers is in a position of major contradiction, is the major power for the change of the international order, plays an important and even decisive role for the world peace and development. Although China is still a great growing country, but it has already set up the image of a responsible big country and has an important influence on international affairs, thus it inevitably has to deal with the powers, which calls for China's diplomacy handling the relation well with the major Western countries and the developed countries necessarily. In addition, the awareness and strategy of major 
power is one important compositive part of one country's comprehensive national strength, China will never become a real sense of the big powers if there is no awareness and strategy of major power. For China's essential task of domestic modernization, it also needs to set the relations with the major Western countries at the primary position in the foreign relationship. Regarding the relations with the developed countries as the focus or key, not only conforms to China's national interests, is also seeking truth from facts, advance with the times approach.

\subsection{Develop pragmatic relations with the great powers}

China's great power diplomacy should adhere to the principle of independence, according to the breadth and depth of different interests' intersection with the major powers, behave pragmatically, deal with neatly and develop different relations with them in different areas and levels. Relations between the great powers have always been both cooperative and competitive, both harmonious and frictional, and mutually precaution and rely on each other. China develops the relations with the great powers, insisting nonalignment, non-confrontation and not targeting at any third party, and always setting safeguarding the country's sovereignty and security in the first place. To that end, we should make every effort to seek advantages and avoid disadvantages, and develop positive factors and resolve negative factors. China and the United States both rival to each other, and there are a lot of common interests. Therefore, for the relation with the United States, we must both cooperate at the same time don't avoid struggle, the cooperation should be maintained in a certain distance, the struggle must be reasonable, beneficial and restricted so that it will not break. For Japan, China should deal with it from the angle of against the United States, the biggest strategic threat of China, and try to make the gradual improvement of bilateral relations between the current stalemates. Involved in the historical, territorial and other sensitive issues, China must uphold the principles and show the necessary flexibility, pay attention to the hardware as well as not stalemates and capture the best time to improve the relations between the two countries in a certain degree. Major EU countries had no direct interests' conflict with China. They are important relying force for China in expanding strategic space. China and Russia should continue to strengthen high-level exchanges and personnel exchanges and enhance mutual political trust, expand economic and trade contacts, consolidate the material foundation of bilateral relations, so that further deepen the strategic partnership between the two countries.

\subsection{China's peaceful development clears up Western's "China threat theory"}

After implementation reform and opening up policy, the comprehensive national strength and international influence of China is increasing gradually, this result in a number of Western countries extreme panic. Various forms of "China threat theory" are rampant right now. Regarding China's development and strengthening, some countries from the reality of international relations theory, think that the rise of China must be accompanied by external expansion and is bound to pose a challenge to the existing big country in the world or even conflict with them, thereby undermining world peace and stability. April 24, 2004, in the opening ceremony of the Boao Forum for Asia, in a speech, President Hu Jintao declared and commitment to the world: "China will adhere to the road of peaceful development, held highly the peace, development and cooperation flag, together with Asian countries create the new situation of Asia revitalization, and strive to make greater contributions to the grand cause of peace and development of mankind's. It comforts the world people undoubtedly. As an emerging power, China's peaceful rise has diametrically different way with the traditional great powers.

In particular, we should point out: Diplomatic focus does not mean a basic diplomatic standpoint for diplomatic focus must rely on basic diplomatic standpoint so that it can be maintained, diplomatic focus and basic diplomatic standpoint is the two important and indispensable elements of the all-round diplomacy, in China's diplomatic strategy, they supplement and promote each other. We can't emphasize one side and ignore or neglect the other side. Whichever country wants to better develop, firstly, they must their position accurately, find their coordinate location in the world order and determine their own diplomatic position (basic diplomatic standpoint). Before reform and opening up, for a variety of reasons, the new China has been in a state of poor and weak and survives only in the crack of big country in the world. Even though relations with great powers are extremely important, it can't be mentioned on China's diplomatic agenda. However, after the reform and opening up, especially in recent years, China's national strength has been enhanced constantly and established position as a great country gradually, China has capital of being a big country, so giving prominence and developing actively the diplomacy with the great powers is the inevitable result of China's national strengthening. The report of he 16th CPC National Congress set the diplomacy with great powers primarily, this just put up the objective existing thing in a pragmatic manner, narrowed the gap existing between the policy statements and diplomatic practice for many years and reflected China's diplomacy develops in a more pragmatic and rational direction, but it does not reflect the inclination to the developed countries of China's diplomacy or the declination of the importance of developing countries. We should realize clearly that: China is a big country, but it was an even more developing countries and is one member of the broad Third World (Note). Therefore, for China, the status of the Third World has not declined, nor decreased, the Third World is still the foundation of China's diplomacy. China's diplomacy still need to be established in the Third World, this is wise and in line with China's national conditions and the fundamental interests of Chinese people. 


\section{References}

Chen, Lemin. (1995). The History of Western Diplomatic Thinking. Chinese Social and Science Press.

Fei, Yan. (1999). The Direction of African External Policy between two Centuries. The West Asia and Africa.

Jiang, Zemin. (1999). Meeting the Leader of the EU. People's Daily. Nov. 22, 1999.

Kenneth, Waltz. (1979). Theory of International Relations, Reading, MA: Addisorr Wesley Publishing Company.

Shi, Lin. (1989). The External Economic Cooperation of Temporary China. Chinese Social and Science Press.

The Research Room of Center Committee of CPC. (1990). The Diplomatic Collectanea of Enlai, Zhou. The Center Literature Press.

The Research Room of Center Committee of CPC. (1994). The Diplomatic Collectanea of Zedong, Mao. The Center Literature Press, The World Knowledge Press.

Tian, Zengpei. (1993). Chinese Diplomacy after Reformation and Opening up. The World Knowledge Press.

Zhang, Qingmin. (2001). The Same Policy on Many Different Countries-Analysis on Chinese Policy on the Developing Countries, The Research on Chinese Temporary History.

Zhang, Qingmin. (2004). The Three-Dimensional Development of Chinese Diplomacy. The Transaction of Diplomacy College.

\section{Notes}

Note 1. Despite the achievements of china have attracted worldwide attention, but China is still the world's largest developing countries and is facing with very arduous task of the development. According to the latest statistics of World Bank and the fresh data that China published recently, the total volume of China's economy in 2004 is only 16.6 percent of the United States, the per capita GDP only amount to 3.6 percent of the United States, 4.0 percent of Japan, in the 208 world countries and regions is No. 129. By the end of 2004 in China's rural areas, there are still 26.1 million people living below the poverty line. Every year we need to address near 24 million people' employment of urban and rural, and there are over 100 million rural labor need to transfer employment. Sources of information: "The White Paper on 'China's road of peaceful development'", seeing http: // politics. people.com.cn/GB/8198/ 3965187.html. Additionally, the data indicate that China is still a "society-owes-developed" country. In 2003, China's first social modernization index was 73 point, in 109 countries is No. 57, second social modernization index for the 28 points, No. 59 , comprehensive social modernization index for the 25 points, ranking No. 60 . The social level of China departs far from the world's advanced level obviously. 